\title{
高脂血症患者における腎機能の血清アポ A-IV 濃度に及ぼす影響*
}

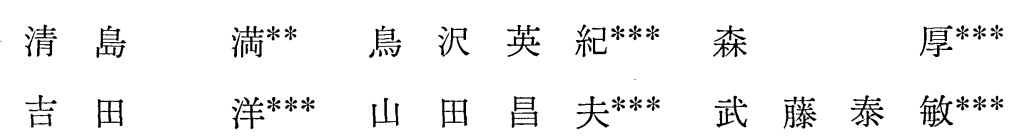

\section{I. 目 的}

アポ A-IV は脂肪吸収の際，小腸粘膜において 合成されるアポ蛋白である1)。しかし血中におけ る動態拉よび機能，またその臨床的意義も十分に 明らかにされていない. 今回高脂血症患者を対象 として血清アポ A-IV 濃度を測定し, 血清脂質お よび他のアポ蛋白濃度と比較検討した．また腎機 能との関連を明らかにするため, BUN および血 清クレアチニン $(\mathrm{Cr})$ 濃度も同時に測定した.

\section{II. 対象と方法}

二次性高脂血症患者77例を対象とし，その内訳 けは IIa 型21例 (52士9 歳，男 7 例，女14例)，IIb 型24例 (49土11歳, 男 10 例, 女 14 例), III 型 2 例 ( $28 \pm 6$ 歳, 男 2 例), IV 型 28 例 ( $46 \pm 12$ 歳, 男 19 例, 女 9 例), $\mathrm{V}$ 型 2 例 ( $35 \pm 8$ 歳, 女 2 例) であ る. また, 正脂血症者 34 名 $(41 \pm 11$ 歳, 男 15 名, 女19名)をコントロール群とし，いずれも早朝空 腹時に採血しその血清を試料とした。

アポ A-I, A-II, B, C-II, C-III, E は第一化学社 製プレートを用い，SRID 法により測定した：ア ポ A-IV は既報2)により作製した自家製の抗血清 を用い，SRID 法により測定した。な㧍 QS 血

$* 1987$ 年 2 月, 日本動脈硬化学会 昭和 61 年度冬季 大会に扔いて発表

** 岐阜大学医学部臨床検查医学

*** 同 第一内科

原稿受取日：1987 年 4 月 14 日

採用決定日：1987 年 7 月 22 日
清® (ヘキスト社) に含まれるアポ A-IV 濃度を $100 \mathrm{U} / \mathrm{d} l$ とし, 試料濃度はそれに対する相対值と して表わした. total cholesterol (TC), triglyceride (TG) は酵素法, HDL-cholesterol (HDL-C) はリ ンタングステン酸- $\mathrm{Mg}^{2+}$ 法により測定した。 また BUN は酵素法, Cr は Jaffé 法により測定した.

\section{III. 結 果}

コントロール群および各型別の高脂血症患者 の血清脂質, BUN, Cr およびアポ蛋白濃度を Tables 1, 2 に示した.なお III 型と V 型は例数不 足のため有意差検定を行わなかった. アポ A-IV はコントロール群に比しIIb 型において有意に高 值を示した $(\mathrm{p}<0.05)$ が，IIa，IV 型は有意差を認 めなかった。 また例数が少ないが III 型, V 型も 若干高い傾向が認められた。なお IIb 型は BUN も有意に高值であった。その他のアポ蛋白に関し ては諸家の報告3) と近似していた.

また全高脂血症患者のアポ A-IV は $126 \pm 42.0$ $\mathrm{U} / \mathrm{d} l$ でコントロール群に比し高い傾向が認めら れたが有意差は認められなかった. そこで高脂血 症患者を $\mathrm{BUN} \geqq 20 \mathrm{mg} / \mathrm{d} l$ の群 $(\mathrm{n}=16)$ と $\mathrm{BUN}<$ $20 \mathrm{mg} / \mathrm{d} l$ の群 $(\mathrm{n}=61)$ に分類して検討すると, $\mathrm{BUN} \geqq 20 \mathrm{mg} / \mathrm{d} l$ の群のアポ A-IV は $149 \pm 43.1 \mathrm{U} /$ $\mathrm{d} l$ で $\mathrm{BUN}<20 \mathrm{mg} / \mathrm{d} l$ の群 $121 \pm 40.0 \mathrm{U} / \mathrm{d} l$ および コントロール群 $116 \pm 28.8 \mathrm{U} / \mathrm{d} l$ に比べ有意に高值 であった.なお IIb 型において BUN $\geqq 20 \mathrm{mg} / \mathrm{d} l$ の症例は 8 例含まれており,これらの症例を除い た IIb 型のアポ A-IV は $128 \pm 44.0 \mathrm{U} / \mathrm{d} l$ となり, 
コントロール群との間に認められた有意差は消失 した.

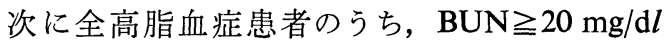
の群におけるアポ A-IVと他の項目 (TC, TG, HDL-C,アポ A-I, A-II, B, C-II, C-III, E, BUN, Cr) との相関を検討した.アポ A-IV は BUN $(\mathrm{r}=0.594, \mathrm{p}<0.01)$ お よび $\mathrm{Cr}(\mathrm{r}=0.626, \mathrm{p}<0.01)$ との間にのみ有意な相関が認められた。

\section{IV. 考察および結論}

アポ A-IV は脂肪吸収に関与していることから， 現在まで吸収不良症候群や慢性膵炎 ${ }^{4)}, \mathrm{TPN}$ 施行 患者2), 胆汁うっ滞症5,6) において血中アポ A-IV が低值となることが報告されている。 また慢性腎 不全においては逆に高值となることも指摘されて おり ${ }^{7,8)}$, 次第にその臨床的意義が明らかにされ つつある.

今回の高脂血症患者におけるアポ A-IVの検討 ではIIb 型のみ有意に高值を示した。しかし同時 に BUN も有意に高值であり，腎機能障害をもつ 症例が比較的多く含まれていたことを示している.
実際に BUNミ20 mg/d $l$ の症例を除いた IIb 型の アポ A-IV はコントロール群と有意差はなく，こ れは全高脂血症患者についても同様の結果が得ら れている.すなわち腎機能の低下が血中アポ A-IV 濃度の上昇に強く関与していることが示唆される. またアポ A-IV が BUN および Cr と有意な正相 関を示していることはこのことを支持する結果と 考えられる.

一方，少数例であったが III 型および V 型にお いてアポ A-IV が高い傾向が認められたのは，確 かに Nestel らマ) のいうレムナントの異化障害が その上昇の一因になっている可能性があると考え られる。しかしいずれがその主たる原因かに関し ては,さらに詳細な検討を要する。

以上より，高脂血症患者においてアポ A-IV は 若干高い傾向が認められたが，それは主として腎 機能の低下している症例が含まれていたためと考 えられ，少なくとも IIa, IIb, IV 型において腎機 能が正常な場合，アポ A-IV 濃度は正常であると 考えられた.

Table 1 Serum lipids (TC, TG, and HDL-C), BUN, and serum creatinine levels in patients with hyperlipidemia and healthy controls

\begin{tabular}{llllll}
\hline & \multicolumn{1}{c}{ TC } & \multicolumn{1}{c}{ TG } & \multicolumn{1}{c}{ HDL-C } & \multicolumn{1}{c}{ BUN } & Creatinine \\
\hline IIa & $249 \pm 28.2^{* * *}$ & $104 \pm 34.6$ & $51.4 \pm 13.3$ & $15.6 \pm 3.3$ & $1.21 \pm 0.67$ \\
IIb & $268 \pm 34.1^{* * *}$ & $336 \pm 193^{* * *}$ & $43.0 \pm 15.1$ & $18.1 \pm 5.4^{*}$ & $1.21 \pm 0.59$ \\
III & $369 \pm 65$ & $423 \pm 86$ & $27.0 \pm 6.2$ & $16.8 \pm 3.6$ & $1.15 \pm 0.7$ \\
IV & $196 \pm 21.6^{*}$ & $250 \pm 108^{* * *}$ & $34.3 \pm 8.0^{* * *}$ & $15.6 \pm 4.0$ & $1.12 \pm 0.14$ \\
V & $268 \pm 20.5$ & $886 \pm 264$ & $32.0 \pm 8.8$ & $22.7 \pm 3.0$ & $1.50 \pm 0.14$ \\
Controls & $179 \pm 32.9$ & $101 \pm 41.8$ & $49.7 \pm 12.7$ & $14.9 \pm 3.6$ & $0.92 \pm 0.4$ \\
\hline
\end{tabular}

$($ mean \pm S.D. $\mathrm{mg} / \mathrm{d} l)$

$* \mathrm{p}<0.05 ; \quad * * * \mathrm{p}<0.001$.

Table 2 Serum apolipoproteins (apo A-I, A-II, A-IV, B, C-II, C-III, and E) levels in patients with hyperlipidemia and healthy controls

\begin{tabular}{llllllcc}
\hline & A-I & A-II & A-IV† & \multicolumn{1}{c}{ B } & C-II & C-III & E \\
\hline IIa & $152 \pm 38.0^{*}$ & $30.3 \pm 8.0$ & $123 \pm 34.9$ & $133 \pm 25.6^{* * *}$ & $4.3 \pm 1.1$ & $8.8 \pm 2.0^{* * *}$ & $5.2 \pm 1.1^{* * *}$ \\
IIb & $156 \pm 45.2^{*}$ & $31.7 \pm 6.0^{*}$ & $144 \pm 49.1^{*}$ & $144 \pm 25.0^{* * *}$ & $7.3 \pm 3.0^{* * *}$ & $17.8 \pm 7.6^{* * *}$ & $8.1 \pm 3.3^{* * *}$ \\
III & $143 \pm 33.0$ & $42.0 \pm 13$ & $148 \pm 34.5$ & $186 \pm 39.0$ & $13.5 \pm 3.5$ & $26.3 \pm 8.3$ & $21.4 \pm 4.8$ \\
IV & $133 \pm 30.0$ & $30.5 \pm 6.2$ & $113 \pm 36.8$ & $117 \pm 23.1^{* * *}$ & $6.2 \pm 2.3^{* * *}$ & $13.7 \pm 3.3^{* * *}$ & $6.6 \pm 2.4^{* * *}$ \\
V & $152 \pm 21.2$ & $28.5 \pm 6.6$ & $179 \pm 43.0$ & $108 \pm 44.0$ & $15.6 \pm 5.4$ & $32.8 \pm 6.8$ & $9.3 \pm 2.4$ \\
Controls & $129 \pm 16.9$ & $28.5 \pm 4.1$ & $116 \pm 28.8$ & $89.2 \pm 26.9$ & $3.7 \pm 1.4$ & $6.1 \pm 2.7$ & $2.7 \pm 1.6$ \\
\hline
\end{tabular}

$($ mean \pm S.D. $\mathrm{mg} / \mathrm{d} l) \dagger($ mean \pm S.D. $\mathrm{U} / \mathrm{d} l$ )

$* \mathrm{p}<0.05 ; \quad * * * \mathrm{p}<0.001$. 


\section{文献}

1) $\mathrm{Wu}, \mathrm{A}$. L. and Windmueller, H. G.: Identification of circulating apolipoproteins synthesized by rat small intestine in vivo. J. Biol. Chem., 253: 25252528 (1978).

2) Seishima, M., Mori, A., Kawade, M., Okuno, F., Yoshida, T. and Muto, Y.: Determination of serum apo A-IV concentration in patients receiving total parenteral nutrition. Gastroenterol. Jpn., 20: 558-563 (1985).

3) 亀田 芳, 松沢佑次, 垂井清一郎：高脂血症各型に おけるアポ蛋白組成. Prog. Med., 4: 2021-2026 (1984).

4) Koga, S., Miyata, Y., Funakoshi, A. and Ibayashi, H.: Plasma apolipoprotein A-IV levels decrease in patients with chronic pancreatitis and malabsorp- tion syndrome. Digestion, 32: 19-24 (1985).

5) 清島 満, 森 厚, 奥野文隆, 吉田 貴, 山田昌 夫, 武藤泰敏, 川出眞坂：肝・胆道疾患における血 清アポ A-IV 濃度の測定とその臨床的意義. 肝臟, 27: 1518-1525 (1986)

6) Miyata, Y., Koga, S. and Ibayashi, H.: Alterations in plasma levels of apolipoprotein A-IV in various clinical entities. Gastroenterol. Jpn., 21: 479-485 (1986).

7) Nestel, P. J., Fidge, N. H. and Tan, M. H.: Increased lipoprotein-remnant formation in chronic renal failure. N. Engl. J. Med., 307: 329-333 (1982).

8) 清島 満, 川出畐坂, 神野英毅, 森厚, 奥野文 隆，山田昌夫，武藤泰敏：腎疾患における血清アポ A-IV 濃度とその臨床的意義. 脂質生化学研究, 28: 385-388 (1986).

\title{
Summary
}

\section{Influence of Renal Function on Values of Serum Apo A-IV in Patients with Hyperlipidemia}

\section{Mitsuru Seishima*, Hidenori TorizawA**, Atsushi Mori**, Hiroshi YoshidA**, Masao YAMADA** and Yasutoshi MUTo**}

\begin{abstract}
*The Department of Laboratory Medicine, **The First Department of Internal Medicine,
\end{abstract} Gifu University School of Medicine

Serum apo A-IV concentrations were determined in 77 patients with various types of hyperlipidemia and 34 healthy controls by means of SRID. The mean value of apo A-IV in hyperlipidemic patients was $126 \pm 42.0 \mathrm{U} / \mathrm{d} l$ which was not significantly high as compared with that in controls $(116 \pm 28.8 \mathrm{U} / \mathrm{d} l)$. However, apo A-IV level in hyperlipidemic patients with azotemia (BUN $\geqq 20 \mathrm{mg} / \mathrm{d} l$ ) was significantly higher than that in those without azotemia $(\mathrm{p}<0.05)$ and that in controls $(\mathrm{p}<0.01)$.

In hyperlipidemic patients with azotemia, there were significant correlations were between apo A-IV and BUN $(r=0.594, p<0.01)$ or serum creatinine $(r=0.626, p<0.01)$ levels, although no sig- nificant correlation was observed between apo AIV and serum lipids (TC, TG, and HDL-C) or other apolipoproteins (apo A-I, A-II, B, C-II, C-III, and E) levels.

In view of the significant correlation between apo A-IV and BUN or serum creatinine levels, we suggest that apo A-IV levels are regulated by the degree of impairment in renal function. Therefore, it is necessary to give full consideration to evaluate the serum apo A-IV levels clinically, particularly in the case of which level shows high, because of above reason.

Key words: apo A-IV, hyperlipidemia, BUN, creatinine, renal function. 